\title{
Effect of Acicnemis variegatus Fairmaire (Curculionidae) on some Ludwigia spp. in Ile-Ife, Nigeria
}

\author{
Matthew OZIEGBE and Julius Olaoye FALUYI \\ Department of Botany, Obafemi Awolowo University, Ile Ife, Nigeria. \\ Corresponding author; E-mail: matthewoziegbe@yahoo.com; Tel: +234 08053445114
}

\begin{abstract}
This study investigated the effect of Acicnemis variegatus on reproductive and growth parameters of five Ludwigia spp [L. octovalvis var brevisepala (Jacq.) Raven, L. decurrens Walter, L. hyssopifolia (G.Don) Excell, L. erecta (Linn) Hara and L. leptocarpa (Nutt.) Hara]. The larva of Acicnemis variegatus significantly reduced the fruit length and the total number of seeds per fruit but increased fruit diameter in L. octovalvis, $L$. erecta and $L$. hyssopifolia. The number of primary branches, number of flowers and fruits were significantly reduced in L. hyssopifolia and L. erecta suggesting abortion of flowers due to presence of larva. Total number of larva per fruit ranges from one to two in fruits of affected exposed Ludwigia species in which they pupate and make a tiny hole which serve as exit. Adult A. variegatus were only found on Ludwigia species during flowering, often mounted on each other or singly on flower buds, bloomed flowers and developing leaves of affected Ludwigia species. A. variegatus did not affect exposed $L$. decurrens and L. leptocarpa. The result suggests that adult $A$. variegatus do not feed on the Ludwigia spp. studied. The significant reduction in number of seeds due to the presence of larva in fruits of affected plants could be an important agent in reducing plant densities.
\end{abstract}

(c) 2010 International Formulae Group. All rights reserved.

Keywords: Acicnemis variegates, Larva, Ludwigia spp., fruits, seeds, vegetative.

\section{INTRODUCTION}

Insects account for more than half of the number of plant and animal species on earth (Wheeler, 1990) constituting an important element of biodiversity. The genus Acicnemis belongs to the family Curculionidae in the order Coleoptera. The family Curculionidae is the largest family of organisms known today. More than 47930 species in 4300 genera are currently recognized (Anderson, 1995; Kuschel, 1995). The genus Acicnemis consist of 194 species and subspecies distributed worldwide.
Acicnemis species have been reported to be abundant and wide spread in Polynesia and on Fiji Island in Australia (Prado, 2006). They are present in many parts of Africa including Nigeria. The vast majority of weevil species are strictly phytophagous as adults and larvae although a few are saprophytic. Even those taxa that are hypogean in habits appear to feed primarily on roots (Ohsawa, 2005). Virtually all higher plant taxa in both terrestrial and freshwater habitats, and all plant parts, are fed upon by weevils (Crowson, 1981). Adult Acicnemis dumalis Faust are fruit feeders 
(Bigger, 2009). Adult Acicnemis crassiusculus are pest found feeding on fruits of Carica papaya but breeds on Hibiscus tiliaceus (Zimmerman, 1993). According to Prado (2006), adult Acicnemis variegatus do feed on leaves of Carica papaya and Mangifera spp. Most Curculionidae larvae live inside the tissues of the host plant but some feed externally on leaves. The adults feed on leaves, pollen, flowers, developing fruit, or fungi and some burrow in wood; they do not necessarily feed on those plants preferred by the larvae. Many weevils are host specific and some are economic pests (Anderson, 1995).

Adult and larva feeding habits of weevils may vary extensively, but species of Curculionidae are loosely classified into 2 groups. In one group, adults and larvae tend to be polyphagous in which the larvae of most species feed externally upon roots in the soil although a few are leaf miners or feed externally on foliage. In the second group, both adults and larvae have a more restricted taxonomic range of host plants (i.e. they are host specific), while some are economic pest. Larvae of most Curculionidae species are internal feeders on other parts of the plant such as the stem, leaves, or reproductive structures. Larvae of few species are external feeders on plant foliage. The Curculionidae are a very important group economically. Not only are some species serious pests of various agricultural crops or of the forestry industry, but others are proving extremely valuable as biological control agents of pest or noxious weeds and as pollinators (O'Brien, 1995).

The genus Ludwigia belongs to the family Onagraceae (Evening-primroses) in the order mytrales comprises 655 species across 17 genera (Levin et al., 2003). Ludwigia is a pantropical genus that is also well represented in the temperate North America and has three endemic taxa in temperate Asia. It includes some 82 species distributed among 23 sections. Twenty five of these species occur in the old World, including 8 of its 23 sections.
A very diverse assemblage of Ludwigia species occur in South America, where 45 of the 82 species occur with most primitive species, and which may have been the centre of origin for the genus and the family Onagraceae (Ramamoorthy and Zardini, 1987; Peng, 1989). A total of 11 species of Ludwigia are endemic to the old world (Raven 1963; Raven and Tai, 1979). In West Africa, they are represented by fourteen species (sixteen taxa) and nine species (eleven taxa) of these are found in Nigeria (Wogua and Ugborogho, 2000).

However, all the invasive species of Ludwigia belong to the Oligospermum section of the genus, of which probably none are native to Nigeria. The water primroses, species have the potential to dominate the shoreline vegetation if introduced to lakes, river, ponds, ditches or streams. They are very difficult to control once established. Biological control is currently considered the only feasible method to confront this weed complex. Reproduction (vegetative or sexual) is an important step in the spread and maintenance of plants (Richardson et al., 2000). Efficient management of weeds cannot be done without sufficient knowledge of the reproduction and propagation modes of noxious weeds (Forman and Kesseli, 2003). Ludwigia species reproduce through sexual or vegetative reproduction but seeding has been the major means of plant establishment in most erect species. Surveys in Argentina revealed the existence of at least 12 insects and pathogens very damaging to the native plants. Ludwigia species have been reported to block slow flowing water ways; they affect irrigation and drainage in lakes, ponds and ditches (Shapperd et al., 2006). Ludwigia taxa have been classified among the 200 most aggressive world plant invaders (Cronk and Fuller, 1995). Ludwigia leptocarpa, $L$. adscendens, L. hyssopifolia, L. erecta and $L$. octovalvis are serious weeds of rice padis and other cultivated swamp lands in Sierra leone, 
Nigeria, Gambia and Ghana; L. adscendens has also been reported to harbour snails, vectors of Schistosomiasis (Burkill, 1997). $L$. decurrens which is an erect annual herb have been observed to form a monotypic stands serving as threats to cultivated plants in aquatic habitat in Ile-Ife, Nigeria (Sakpere et al., 2010).

There are no reports on insect interactions on members of this genus in Nigeria. Adult Acicnemis variegatus weevil and their larvae are recently been observed on some Ludwigia species grown at the Department of Botany, Obafemi Awolowo University, Ile-Ife and in their natural habitats, this necessitated the investigation of the effects of this weevil on some Ludwigia species. The aim of this study is to determine the effect of the weevil on the vegetative growth and reproduction of Ludwigia leptocarpa, L. decurrens, L. hyssopifolia, L. erecta and L. octovalvis.

\section{MATERIALS AND METHODS}

The experiment was carried out at the Department of Botany, Obafemi Awolowo University, Ile-Ife. The seeds of L. octovalvis, L. hyssopifolia, L. erecta, L. decurrens and $L$. leptocarpa used for the experiment were collected from the wild along Ede road in IleIfe, Osun State. Seeds of each Ludwigia species were placed separately in $8.00 \mathrm{~cm}$ Petri dishes lined with No.1 Whatman filter paper and seeds were watered regularly with distilled water. Seedlings were subcultured into a nursery immediately after germination. Three weeks after germination seedlings of each Ludwigia species were transplanted into 7 litres plastic buckets filled with topsoil. On each of the species there were five replicates each for the control, which were caged in a mosquito net wire gauze to keep them under a control environment, to prevent being susceptible to the insect pest (protected from insects) and five replicates for each of the species which were not caged (exposed to insects). The plants were watered regularly to keep the soil moist. The day of first flowering was observed for each of the species. At first flowering plant height, number of primary branches, number of flowers and number of fruits were observed. These readings were observed for each species every four weeks for twelve weeks for each treatment. The numbers of seeds per fruit, fruit length and fruit diameter in the exposed and protected plants in each species were also determined from fifty randomly selected fruits per species. The insect (Acicnemis variegatus (Fairmaire) was identified at the insectarium of the Department of Crop production and Protection, Faculty of Agriculture, Obafemi Awolowo University, Ile-Ife.

\section{Statistical analysis}

All statistical analyses were performed using system analysis software (SAS) version 9.2. To examine how reproductive and vegetative parameters of exposed plant species varied from plants protected from insects. Data obtained were subjected to oneway analysis of variance (ANOVA) at probability level of 0.05 .

\section{RESULTS}

On exposed Ludwigia species it was observed that Acicnemis variegatus were not found on any of the Ludwigia species until the development of flower buds. They were constantly found on top of each other or individually on flower buds, bloomed flowers and tip of the stems. Total number of larva per fruit of affected Ludwigia spp studied ranges from $1-2$; in $L$. octovalvis $(1.49 \pm 0.10)$ and $L$. erecta $(1.30 \pm 0.06)$ but only one larva per fruit was observed in L. hyssopifolia (1.00 \pm 0.00). A. variegatus larvae were not present in fruits of exposed $L$. decurrens and $L$. leptocarpa. In L. octovalvis, L. hyssopifolia and $L$. erecta fruit diameter was significantly bigger in exposed plants than in protected plants; fruit length of protected plants was significantly longer than fruit length of 
exposed plants; total number of seeds per fruit was significantly less in exposed than in protected plants (Table 1).

In L. decurrens, L. hyssopifolia, $L$. erecta and L. leptocarpa there were no significant differences in plant heights of protected and exposed plant throughout the weeks (Table 2). In L. octovalvis, plant height of exposed plant was significantly reduced at week 4 compared to heights in protected plants (Table 2). In L. octovalvis, L. decurrens and L. leptocarpa there were no significant differences in the number of primary branches produced in protected and exposed plants throughout the weeks (Table 3). In $L$. hyssopifolia and L. erecta number of primary branches in the protected plants was significantly higher than the number of primary branches in the exposed plants at week 4, 8 and 12 (Table 3). In L. octovalvis, L. decurrens and L. leptocarpa there were no significant differences in the number of flowers and number of fruits produced in the protected and exposed plants throughout the weeks (Table 4 and 5). In L. hyssopifolia, the number of flowers and number of fruits produced by protected plants were significantly higher than in exposed plants at week 8 and 12 (Table 4 and 5). Protected plants of $L$. erecta produced significantly higher number of flowers in week 4 and 8 (Table 4). Number of fruits in protected plants of $L$. erecta were significantly higher than the number of fruits in exposed plants at week 4, 8 and 12 (Table 5).

\section{DISCUSSION}

Result observed (Table 1) shows that the fruit diameter of the infected plants exposed to insect was wider than the fruit diameter of protected plants in L. octovalvis, L. hyssopifolia and L. erecta. This is as a result of the larva creating a cocoon in the fruits. The significant reduction in fruit length and the number of seeds per fruit observed in the exposed Ludwigia species is as a result of the presence of larva in the fruit which use the developing fruit as source of food leading to reduction in number of seeds. Ludwigia species have been reported to produce high number of seeds, high number of fruits with high percentage germination. Significant reduction in number of seeds might reduce plant densities to some extent; this might also reduce the seed bank. Herbivory of weevil can reduce plant growth, seed set and survival if the plants are seed limited (Maron and Vila, 2001; Maron et al., 2002). Though some studies (Andersen, 1989; Cilliers and Nesers, 1991; Faithfull, 1997; Hoffmann and Moran, 1998) have reported that sometimes reduction in seed production by seed predating agents do not reduce plant abundance when they are habitat limited. Several studies support the role of specialist insect in reducing plant abundance via seed predation. Seed feeding herbivores significantly affect demography abundance of two perennial plant (Golden bush (Hazardia squarrosus) and also Platte thistle (Cirsium canescens) resulting in a 31 to $61 \%$ reduction in seed production (Louda, 1982; Louda and Potvim, 1995). The presence of adult A. variegatus most often on flower buds and bloomed flowers is as a result of the weevils trying to oviposit on them. Several species of weevil have been known to feed on the seed of wild Leguminaceae in which the female oviposit on fruit (pods) or seeds. The larva feed inside a seed or seeds and then pupate inside in a protected place most of which are host specific (Ted and Clarence, 1974). Beetles prefer plants with indehiscent and tardily indehiscent pod (Ted and Clarence, 1974). This study observed that the cocoon created by larva prevent dehiscence of fruit at ripening, which allow the larva to develop and pupate but prevent early seed dispersal. 
M. OZIEGBE and J. O. FALUYI/Int. J. Biol. Chem. Sci. 4(6): 2026-2034, 2010

Table 1: Fruit length, fruit diameter and total number of seeds per fruit in protected and exposed Ludwigia spp.

\begin{tabular}{|c|c|c|c|c|c|c|}
\hline & \multicolumn{2}{|c|}{ Fruit length $(\mathrm{cm})$} & \multicolumn{2}{|c|}{ Fruit diameter $(\mathrm{cm})$} & \multicolumn{2}{|c|}{ Number of seeds per fruit } \\
\hline & Protected & Exposed & Protected & Exposed & Protected & Exposed \\
\hline L. hysopifolia & $1.95 \pm 0.02$ & $1.24 \pm 0.03 *$ & $0.10 \pm 0.00$ & $0.24 \pm 0.01 *$ & $249.47 \pm 0.00$ & $88.92 \pm 0.01 *$ \\
\hline L. decurrens & $1.92 \pm 0.05$ & $1.85 \pm 0.03 \mathrm{~ns}$ & $0.48 \pm 0.01$ & $0.49 \pm 0.01 \mathrm{~ns}$ & $2496.30 \pm 24.78$ & $2491 \pm 22.78 \mathrm{~ns}$ \\
\hline L. leptocarpa & $3.52 \pm 0.04$ & $3.48 \pm 0.06 \mathrm{~ns}$ & $0.28 \pm 0.01$ & $0.27 \pm 0.01 \mathrm{~ns}$ & $382.40 \pm 9.24$ & $379.60 \pm 8.63 \mathrm{~ns}$ \\
\hline
\end{tabular}

Table 2: Plant heights (cm) of Ludwigia spp. over a period of 12 weeks after first flowering.

\begin{tabular}{|c|c|c|c|c|c|c|c|c|}
\hline & \multicolumn{2}{|c|}{ Week one } & \multicolumn{2}{|c|}{ Week four } & \multicolumn{2}{|c|}{ Week eight } & \multicolumn{2}{|c|}{ Week twelve } \\
\hline & Protected & Exposed & Protected & Exposed & Protected & Exposed & Protected & Exposed \\
\hline L. octovalvis & $17.40 \pm 0.56$ & $17.70 \pm 0.44 \mathrm{~ns}$ & $55.06 \pm 0.28$ & $53.74 \pm 0.46 *$ & $66.42 \pm 2.03$ & $63.50 \pm 2.23 \mathrm{~ns}$ & $90.94 \pm 5.50$ & $87.40 \pm 5.16 \mathrm{~ns}$ \\
\hline L. hyssopifolia & $88.40 \pm 1.41$ & $88.08 \pm 1.16 \mathrm{~ns}$ & $169.4 \pm 2.11$ & $169.80 \pm 1.21 \mathrm{~ns}$ & $169.60 \pm 2.09$ & $168.26 \pm 1.91 \mathrm{~ns}$ & $175.78 \pm 1.84$ & $173.76 \pm 1.65 \mathrm{~ns}$ \\
\hline L. erecta & $11.56 \pm 0.19$ & $11.68 \pm 0.48 \mathrm{~ns}$ & $78.56 \pm 0.99$ & $77.04 \pm 0.92 \mathrm{~ns}$ & $105.32 \pm 2.98$ & $102.34 \pm 2.84 \mathrm{~ns}$ & $105.58 \pm 2.93$ & $102.34 \pm 2.84 \mathrm{~ns}$ \\
\hline L. decurrens & $126.42 \pm 4.11$ & $124.92 \pm 3.75 \mathrm{~ns}$ & $242.44 \pm 9.21$ & $239.78 \pm 9.33 \mathrm{~ns}$ & $317.74 \pm 5.26$ & $316.12 \pm 5.28 \mathrm{~ns}$ & $320.08 \pm 3.86$ & $313.86 \pm 3.09 \mathrm{~ns}$ \\
\hline L. leptocarpa & $41.42 \pm 0.96$ & $40.08 \pm 1.14 \mathrm{~ns}$ & $76.68 \pm 1.57$ & $74.88 \pm 1.63 \mathrm{~ns}$ & $87.84 \pm 3.32$ & $85.56 \pm 3.24 \mathrm{~ns}$ & $90.80 \pm 3.44$ & $87.18 \pm 2.93 \mathrm{~ns}$ \\
\hline
\end{tabular}

Table 3: Primary branches of Ludwigia spp. over a period of 12 weeks after first flowering.

\begin{tabular}{|c|c|c|c|c|c|c|c|c|}
\hline & \multicolumn{2}{|c|}{ Week one } & \multicolumn{2}{|c|}{ Week four } & \multicolumn{2}{|c|}{ Week eight } & \multicolumn{2}{|c|}{ Week twelve } \\
\hline & Protected & Exposed & Protected & Exposed & Protected & Exposed & Protected & Exposed \\
\hline L. octovalvis & $12.60 \pm 0.46$ & $12.40 \pm 2.00 \mathrm{~ns}$ & $31.00 \pm 0.69$ & $29.80 \pm 0.52 \mathrm{~ns}$ & $32.60 \pm 1.00$ & $29.80 \pm 0.52 \mathrm{~ns}$ & $38.80 \pm 1.77$ & $32.80 \pm 0.77 *$ \\
\hline
\end{tabular}


M. OZIEGBE and J. O. FALUYI / Int. J. Biol. Chem. Sci. 4(6): 2026-2034, 2010

\begin{tabular}{|c|c|c|c|c|c|c|c|c|}
\hline L. hyssopifolia & $8.00 \pm 0.67$ & $7.40 \pm 0.61 \mathrm{~ns}$ & $25.40 \pm 0.46$ & $22.40 \pm 0.73 *$ & $37.00 \pm 0.89$ & $22.40 \pm 0.73 *$ & $38.00 \pm 1.17$ & $22.40 \pm 0.73 *$ \\
\hline L. erecta & $24.20 \pm 0.57$ & $23.20 \pm 0.53 \mathrm{~ns}$ & $29.60 \pm 0.46$ & $23.40 \pm 0.67 *$ & $38.20 \pm 0.33$ & $23.40 \pm 0.67 *$ & $38.40 \pm 0.36$ & $25.60 \pm 0.92 *$ \\
\hline L. decurrens & $26.80 \pm 1.09$ & $26.00 \pm 0.78 \mathrm{~ns}$ & $42.40 \pm 0.83$ & $41.00 \pm 1.27 \mathrm{~ns}$ & $43.20 \pm 0.77$ & $41.00 \pm 1.27 \mathrm{~ns}$ & $43.20 \pm 0.77$ & $42.60 \pm 1.56 \mathrm{~ns}$ \\
\hline L. leptocarpa & $18.20 \pm 0.51$ & $17.20 \pm 0.77 \mathrm{~ns}$ & $23.80 \pm 0.66$ & $23.20 \pm 0.33 \mathrm{~ns}$ & $23.80 \pm 0.66$ & $23.20 \pm 0.33 \mathrm{~ns}$ & $23.80 \pm 0.66$ & $23.20 \pm 0.33 \mathrm{~ns}$ \\
\hline
\end{tabular}

ns non-significant; * significant at 0.05

Table 4: Number of flowers of Ludwigia spp. over a period of 12 weeks after first flowering.

\begin{tabular}{|c|c|c|c|c|c|c|c|c|}
\hline & \multicolumn{2}{|c|}{ Week one } & \multicolumn{2}{|c|}{ Week four } & \multicolumn{2}{|c|}{ Week eight } & \multicolumn{2}{|c|}{ Week twelve } \\
\hline & Protected & Exposed & Protected & Exposed & Protected & Exposed & Protected & Exposed \\
\hline L. octovalvis & $1.40 \pm 0.22$ & $1.60 \pm 0.22 \mathrm{~ns}$ & $20.80 \pm 0.77$ & $19.20 \pm 0.91 \mathrm{~ns}$ & $0.46 \pm 0.36$ & $0.40 \pm 0.22 \mathrm{~ns}$ & $1.60 \pm 0.36$ & $0.40 \pm 0.22 \mathrm{~ns}$ \\
\hline L. hyssopifolia & $2.80 \pm 0.34$ & $2.60 \pm 0.22 \mathrm{~ns}$ & $12.80 \pm 0.52$ & $8.00 \pm 0.63 *$ & $12.60 \pm 0.83$ & $6.00 \pm 0.57 *$ & $0.00 \pm 0.00$ & $0.00 \pm 00.00 \mathrm{~ns}$ \\
\hline L. erecta & $2.00 \pm 0.00$ & $1.60 \pm 0.22 \mathrm{~ns}$ & $39.80 \pm 2.77$ & $37.40 \pm 3.75 \mathrm{~ns}$ & $34.20 \pm 3.87$ & $22.60 \pm 1.78 *$ & $5.00 \pm 0.63$ & $0.80 \pm 0.33 *$ \\
\hline L. decurrens & $2.80 \pm 0.34$ & $2.60 \pm 0.22 \mathrm{~ns}$ & $19.80 \pm 1.40$ & $19.20 \pm 1.73 \mathrm{~ns}$ & $0.80 \pm 0.52$ & $1.20 \pm 0.34 \mathrm{~ns}$ & $2.20 \pm 0.18$ & $2.00 \pm 0.28 \mathrm{~ns}$ \\
\hline L. leptocarpa & $2.80 \pm 0.66$ & $2.80 \pm 0.32 \mathrm{~ns}$ & $24.80 \pm 1.25$ & $24.60 \pm 1.37 \mathrm{~ns}$ & $0.80 \pm 0.18$ & $1.40 \pm 0.22 \mathrm{~ns}$ & $0.00 \pm 0.00$ & $0.60 \pm 0.22 \mathrm{~ns}$ \\
\hline
\end{tabular}

int; $*$ significant at 0.05

Table 5: Number of fruits on Ludwigia spp. over a period of 12 weeks after first flowering.

\begin{tabular}{|c|c|c|c|c|c|c|c|c|}
\hline & \multicolumn{2}{|c|}{ Week one } & \multicolumn{2}{|c|}{ Week four } & \multicolumn{2}{|c|}{ Week eight } & \multicolumn{2}{|c|}{ Week twelve } \\
\hline & Protected & Exposed & Protected & Exposed & Protected & Exposed & Protected & Exposed \\
\hline L. octovalvis & $0.00 \pm 0.00$ & $0.00 \pm 0.00 \mathrm{~ns}$ & $137.40 \pm 10.78$ & $136.00 \pm 10.14 \mathrm{~ns}$ & $323.60 \pm 13.17$ & $328.00 \pm 18.06 \mathrm{~ns}$ & $387.40 \pm 15.94$ & $374.40 \pm 16.98 \mathrm{~ns}$ \\
\hline L. hyssopifolia & $0.00 \pm 0.00$ & $0.00 \pm 0.00 \mathrm{~ns}$ & $153.40 \pm 4.59$ & $231.60 \pm 7.63 \mathrm{~ns}$ & $444.60 \pm 5.10$ & $391.60 \pm 2.17 *$ & $516.60 \pm 3.86$ & $404.00 \pm 3.10 *$ \\
\hline L. erecta & $0.00 \pm 0.00$ & $0.00 \pm 0.00 \mathrm{~ns}$ & $239.00 \pm 8.29$ & $231.60 \pm 7.62 \mathrm{~ns}$ & $1120.00 \pm 33.20$ & $1042.60 \pm 35.65 \mathrm{~ns}$ & $1197.80 \pm 4.51$ & $1067.60 \pm 34.34 *$ \\
\hline L. decurrens & $0.00 \pm 0.00$ & $0.00 \pm 0.00 \mathrm{~ns}$ & $88.60 \pm 2.91$ & $88.60 \pm 2.56 \mathrm{~ns}$ & $88.60 \pm 2.91$ & $88.60 \pm 2.56 \mathrm{~ns}$ & $282.40 \pm 1.97$ & $280.60 \pm 1.80 \mathrm{~ns}$ \\
\hline L. leptocarpa & $0.00 \pm 0.00$ & $0.00 \pm 0.00 \mathrm{~ns}$ & $277.20 \pm 15.07$ & $231.60 \pm 7.63 \mathrm{~ns}$ & $370.20 \pm 10.94$ & $348.00 \pm 16.67 \mathrm{~ns}$ & $392.20 \pm 10.59$ & $388.60 \pm 10.94 \mathrm{~ns}$ \\
\hline
\end{tabular}


According to Louda et al. (1990), early feeding by insects reduces the release of viable seed in three folds. Janzen (1969) reported that some plants contain toxic deterrent in their seeds which prevent being fed upon by weevils. This might explain why the Acicnemis adult avoided L. decurrens and L. leptocarpa. Johnson (1970) reported that several species of Astragalus which have poisonous seeds were fed upon by seed beetles of genus Acanthoscelides. Also Ted and Clarence (1974) reported the presence of Acanthoscelides alboscutellatus in the fruit of Ludwigia alternifolia and the number of seeds per pod observed were between 2 and 90. A. variegatus significantly reduce flower production in L. hyssopifolia and L. erecta in week 4,8 and 12 resulting in significant reduction in the number of fruits produced but had no effect on L. octovalvis. The larva of Lanophyes marmoratus (Curculionidae) has been reported to damage flower buds and reduce the number of seeds produced by completing their life cycle in the fruit of Lythrum salicari. Monocychus vulpeculus larva has also been reported to complete its life cycle in Siberian irises and Iris versicola which limit seed production and keep plant in check (Room et al., 1985). Hoffman and Moran (1991) reported that weevils can act as a biological control agent in controlling the dispersal of weed. The presence of $A$. variegatus had little effect on growth of affected Ludwigia species. On plant heights, a significant reduction was observed only in $L$. octovalvis at week 4 . This might be because the adult weevil does not feed on the Ludwigia species studied. Adult weevils do not necessarily feed on the plant preferred by the larvae but only come to lay her eggs in the fruit of the plant and does not necessarily feed on it (Anderson, 1997). In L. hyssopifolia and $L$. erecta there were no significant differences in the number of primary branches produced in the protected and affected exposed plants in week 1 but there were significant differences in week 4, 8 and week 12 (Table 2). This implies the presence of larva and weevil affect the production of primary branches in the species.

\section{Conclusion}

The study has shown that Acicnemis variegatus had effects to a large extent on the fruit length, fruit diameter and number of seeds per fruit and has little or no effect on the vegetative parameters of susceptible Ludwigia species studied. There is need to further investigate whether seed reduction by $A$. variegatus larva will lead to reduction in seedling recruitment of affected Ludwigia spp. in their natural habitats.

\section{REFERENCES}

Andersen AN. 1989. How important is seed predation to recruitment in stable populations of long-lived perennials? Oecologia., 81: 310-315.

Anderson RS. 1995. An evolutionary perspective on diversity in Curculionoidea. Mem.ent. Soc. Wash., 14: 103-114.

Anderson RS. 1997. Weevils (Coleoptera: Curculionoidea, Excluding Scolytinae and Platypodinae) of the Yukon. In Insects of the Yukon, Danks HV, Downes JA (eds). Biological Survey of Canada (Terrestrial Arthropods); 523-562.

Burkill HM. 1997. The useful plants of West Tropical Africa. Royal Botanical Gardens Kew., 14: 303-308.

Bigger M, 2009. A geographical distribution list of insects and mites associated with Cocoa, derived from literature published before 2010. pp.1-357.

Cilliers CJ, Neser S. 1991. Biological control of Lantana camara (Verbenaceae) in South Africa. Agric. Ecosyst. Environ., 37: 57-75.

Cronk QCB, Fuller JL. 1995. Plant Invaders: The Threat to Natural Ecosystems. Chapman and Hall: London; 241 
Crowson RA. 1981. The Biology of the Coleoptera. Academic Press: London; 802.

Faithfull I. 1997. Etilla behrii (Zeller) (Lepidoptera: Pyralidae) bred from pods of gorse, Ulex europaeus L. Fabaceae). Victorian Entomol., 27: 34.

Forman J, Kesseli RV. 2003. Sexual reproduction in the invasive species Fallopia japonica (Polygonaceae). Amer. J. Bot., 90: 586-592.

Hoffmann JH, Moran VC. 1991. Biological control of Sesbania punicea in South Africa. Agric. Ecosyst. Environ., 37: 157173.

Hoffmann JH, Moran VC. 1998. The population dynamics of an introduced tree, Sesbania punicea, in South Africa, in response to long-term damage caused by different combinations of three species of biological control agents. Oecologia., 114: 343-348.

Janzen DH. 1969. Seed eaters versus seed size, number, toxicity and dispersal. Evol., 23: $1-27$.

Johnson CD. 1970. Biosystematics of the Arizona, California and Oregon species of the seed beetle genus Acanthoscelides Schilsky (Coleoptera : Bruchidae). University of California Publ. Entomol., 59: 1-116.

Kuschel G. 1995. A phylogenetic classification of Curculionoidea to families and subfamilies. Mem. Ent. Soc. Wash., 14: 5-33.

Levin RA, Wagner WL, Hoch PC, Nepokroeff M, Pires JC, Zimmer EA, Sytsma KJ. 2003. Family-level relationships of Onagraceae based on chloroplast $r b c L$ and $n d h F$ data. Amer. J. Bot., 90: 107-115.

Louda SM. 1982. Distribution ecology: variation in plant recruitment over a gradient in relation to insect seed predation. Ecol.Monogr., 52: 25- 41.

Louda SM, Potvin MA, Collinge SK. 1990. Predispersal seed predation, postdispersal seed predation and competition in the recruitment of seedlings of a native thistle in sandhills prairie. Am. Midl. Nat., 124: 105-113.

Louda SM, Potvim MA. 1995. Effect of inflourescence feeding insects on the demography and lifetime fitness of a native plant. Ecol., 76: 229-245.

Maron JL, Vila M. 2001. When do herbivores affect plant invasion? Evidence for the natural enemies and biotic resistance hypothesis. OIKOS, 95: 361-373.

Maron JL, Julie KC, Svata ML. 2002. Convergent demographic effects of insect attack on related thistles in coastal vs. continental dunes. Ecol., 83: 3382-3392.

O'Brien CW. 1995. Weevils (Coleoptera: Curculionidae, sensu lato) In Precinctive Insect Species in Florida. Frank JH, McCoy CW (eds). Florida Entom., 8: 135.

Ohsawa M. 2005. Species richness and composition of Curcurlionidae (Coleoptera) in a conifer plantation, secondary forest, and old- growth forest in the central mountainous region of Japan. Ecol. Res., 20: 632-645.

Peng CI. 1989. The systematics and evolution of Ludwigia section Microcarpium (Onagraceae). Ann. Missouri Bot. Gard., 76: 221-302.

Prado EM. 2006. Insect biodiversity and assessment of herbivory in a native and non native plants in Mo'rea, French Polynesia. University of California Berkeley Student research papers, pp 113.

Richardson DM, Pysek P, Rejmanek M, Barbour MG, Panetta FD, West CJ. 2000. Naturalization and invasion of alien plants: concepts and definition. Diversity and Distribution, 6: 93-107.

Raven PH. 1963. The Old World species of Ludwigia (including Jussiaea), with a synopsis of the genus (Onagraceae). Reinw., 6: 327- 427. 
Raven PH, Tai W. 1979. Observations of chromosomes in Ludwigia (Onagraceae). Ann. Missouri Bot. Gard., 66: 862- 879.

Ramamoorthy TP, Zardini E. 1987. The systematics and evolution of Ludwigia sect. Myrtocarpus sensu lato (Onagraceae). Monographs in Systematic Botany of the Missouri Bot. Gard., 19: 1120.

Room PM, Sands DPA, Forno IW, Taylor MFJ, Julien MH, 1985. A summary of research into biological control of salvinia in Australia. In: Proceedings of the VI international symposium on biological control of weeds. Delfosse ES (ed). Agriculture Canada: Vancouver; 543-549.

Sakpere AM, Oziegbe M, Bilesanmi IA. 2009. Allelopathic effects of Ludwigia decurrens Walter and L. adscendens subsp. diffusa (Forsk.) Raven on germination, seedling growth and yield of Corchorous olitorious L. Not. Sci. Biol., 2: 75-80.

Sheppard AW, Shaw R, Sforza R. 2006. Top 20 environmental weeds for classical biological control in Europe-a review of opportunities, regulations and other barriers to adaptation. Weed Res., 46: 93117.

Ted DC, Clearance DJ. 1974. Co-evolution of some seed beetles (Coleoptera: Bruchidae) and their hosts. Ecol., 55: 1096-1103.

Wheeler AG. 1999. Otiorhynchus ovatus, O. rugostriatus and O. sulcatus (Coleoptera: Curculionidae): exotic weevils in natural communities, mainly mid-Appalachian shale barrens and outcrops. Proceedings of the Entomological Society of Washington, 101: 689-692.

Wogu A, Ugborogho RE. 2000. Seed morphology, germination and seedling characters in Ludwigia species (Onagraceae) in Nigeria as aids to identification. Seed Sci. Tech., 28: 657697.

Zimmerman EC. 1993. Australian weevils (Coleoptera curculioniodea). CSIRO Publishing Entomological Society of America: Melbourne; 854. 